\title{
The Effect of Liquid Organic Fertilizer (LOF) Made from Rabbit Urine and NPK Fertilizer on the Growth of Bok Choy (Brassica rapa L. Subsp. chinensis)
}

\author{
Legita Dwi Kurnianta ${ }^{1}$, Prapti Sedijani ${ }^{*}{ }^{*}$, Ahmad Raksun ${ }^{1}$ \\ ${ }^{1}$ Program Studi Pendidikan Biologi, Jurusan PMIPA FKIP Universitas Mataram
}

\author{
Article History \\ Received : January $07^{\text {th }}, 2021$ \\ Revised : January $13^{\text {th }}, 2021$ \\ Accepted : January $20^{\text {th }}, 2021$ \\ Published : January $27^{\text {th }}, 2021$ \\ *Corresponding Author: \\ Prapti Sedijani, \\ Program Studi Pendidikan \\ Biologi FKIP Universitas \\ Mataram, Mataram, Indonesia; \\ Email: \\ praptisedijani@unram.ac.id
}

\begin{abstract}
Fertilizer is one of the most important needs for plants. Fertilizing can be done by using inorganic fertilizers or organic fertilizers. Long term fertilizing by using inorganic fertilizers without adding the organic matter could potentially reduce soil fertility and lead to not optimal growth of the plant. This study aims to determine the effect of liquid organic fertilizer (LOF) made from rabbit urine, NPK fertilizer, and the combination of both fertilizers on the growth of bok choy, and to determine the best fertilizer dosage for the growth of bok choy. This study uses a Completely Randomized Design consisting of 2 factors, the dose of rabbit urine LOF and dose of NPK fertilizer; 4 dosage levels each in triplicates. Data was analyzed using ANOVA followed by DMRT Test. The results indicates that the application of LOF made from rabbit urine, NPK fertilizer, and the combination of both fertilizers increases plant height, leaves number, leaf area, wet weight, dry weight, and chlorophyll total of bok choy. DMRT ( $\alpha$ $5 \%$ ) test shows the best dosage applied for enhancing growth parameter are $6 \mathrm{ml}$ of LOF plus 0,4 gram of NPK for plant height, wet weight, and dry weight, the $4 \mathrm{ml}$ of LOF plus 0,6 gram of NPK for leaves number and leaf area, and the $4 \mathrm{ml}$ of LOF plus 0,4 gram NPK for chlorophyll total.
\end{abstract}

Keywords: Liquid Organic Fertilizer; Rabbit Urine; NPK Fertilizer; Growth Of Bok Choy

\section{Pendahuluan}

Pertumbuhan dan produksi tanaman sangat ditentukan oleh sifat tanah dan ketersediaan unsur hara. Tanah yang ditanami terus-menerus tanpa memperhatikan pemeliharaan tanah dapat menyebabkan ketersediaan unsur hara semakin berkurang, bila keadaan seperti ini terus dibiarkan maka tanaman akan kekurangan unsur hara sehingga pertumbuhan tanaman menjadi terganggu (Kriswantoro et al, 2016). Upaya untuk meningkatkan ketersediaan unsur hara dapat dilakukan dengan pemupukan, baik dengan menggunakan pupuk anorganik maupun pupuk organik. Pemupukan bertujuan agar tanaman tetap mendapat makanan yang cukup selama pertumbuhannya dan membuat kondisi tanah memungkinkan tanaman dapat tumbuh dengan baik sehingga dapat meningkatkan produksi tanaman (Mulyani, 2014). Masyarakat sangat

This article is licensed under a Creative Commons Attribution 4.0 International License. bergantung pada peranan pupuk anorganik yang mampu memberikan hasil lebih cepat, praktis, dan mudah didapat, salah satu yang banyak digunakan adalah pupuk NPK. Namun penggunaan pupuk anorganik secara berlebihan dapat menimbulkan dampak negatif seperti pencemaran lingkungan, merusak struktur tanah dan menurunkan tingkat kesuburan tanah (Dewanto et al, 2013; Mulyani, 2014; Rahmanda et al, 2018). Hal ini terjadi karena akumulasi kandungan mineral dalam pupuk anorganik dapat membunuh mikroorganisme yang bertugas melakukan dekomposisi tanah, sehingga tanah menjadi keras serta kurang mampu menahan air dan nutrisi (Mulyani, 2014). Pemupukan dengan pupuk anorganik tanpa pemberian bahan organik pada media tanam dapat menyebabkan bahan organik di dalam tanah berkurang sehingga sifat fisik dan kimia tanah tidak mendukung pertumbuhan tanaman (Susantidiana \& Aguzaen, 2015). Salah satu usaha yang dapat dilakukan 
untuk mengurangi penggunaan pupuk anorganik yaitu dengan mengkombinasi pupuk anorganik dan pupuk organic (Sirot et al, 2017; Raksun et al, 2019). Penggunaan pupuk organik sendiri dapat memperbaiki sifat-sifat tanah untuk meningkatkan pertumbuhan dan produktivitas tanaman secara berkelanjutan (Mulyani, 2014). Pemberian kombinasi pupuk organik dan pupuk anorganik dapat memberikan pertumbuhan dan hasil yang lebih baik terhadap tinggi tanaman, jumlah daun, luas daun, berat basah, berat kering dan hasil per hektar tanaman sawi (Wahid et al, 2015). Kotoran kelinci baik feses maupun urin dapat menjadi sumber pupuk organik yang potensial untuk tanaman hortikultura. Kemampuan kelinci berkembang biak dengan cepat berpotensi menghasilkan kotoran yang banyak, jika tidak dikelola dengan baik akan mengganggu sanitasi lingkungan (Hartini et al, 2019). Urin kelinci mengandung unsur $\mathrm{N}, \mathrm{P}$, dan $\mathrm{K}$ lebih banyak dibandingkan urin sapi dan urin kambing (Khoir et $a l, 2017$ ). Urin kelinci belum banyak dimanfaatkan sebagai pupuk organik karena masyarakat belum mengetahui tentang kandungan dan manfaat urin kelinci dalam meningkatkan pertumbuhan tanaman. Manfaat aplikasi urin kelinci terhadap tanaman sawi dapat meningkatkan tinggi tanaman, jumlah daun, lebar daun, bobot segar dan bobot konsumsi (Mutryarni et al, 2014).

Salah satu tanaman hortikultura yang banyak diminati oleh berbagai kalangan masyarakat adalah sawi sendok atau pakcoy. Sawi sendok dapat digunakan sebagai penghias makanan (garnish) atau diolah dengan cara dimasak. Tanaman sawi sendok dibudidayakan oleh masyarakat karena memiliki komersil dan prospek yang baik (Sukasana et al, 2019). Sayuran ini memiliki nutrisi yang cukup baik untuk tubuh manusia seperti protein, serat, vitamin $\mathrm{A}$, vitamin $\mathrm{C}$, vitamin $\mathrm{K}$, zat besi, folat dan kalium (Tuquero et al, 2018).

Tanaman sawi memerlukan pemupukan yang cukup banyak terutama unsur $\mathrm{N}, \mathrm{P}$, dan $\mathrm{K}$ serta unsur mikro (Mutryarny et al, 2014). Pemupukan yang tidak tepat dapat menyebabkan pertumbuhan tanaman tidak optimal, oleh karena itu, dosis pupuk dan unsur hara yang terkandung dalam pupuk sangatlah penting dalam pemupukan yang efektif. (Kristanto \& Aziz, 2019). Ketergantungan yang besar terhadap pupuk NPK sebagai sumber hara berpotensi menurunkan produktivitas tanah sehingga penggunaannya perlu dikurangi dengan memanfaatkan pupuk organik yang berasal dari urin kelinci. Berdasarkan uraian diatas diperlukan penelitian tentang "Pengaruh POC Urin Kelinci dan Pupuk NPK terhadap Pertumbuhan Tanaman Sawi Sendok".

Adapun tujuan penelitian ini adalah untuk mengetahui (1) pengaruh POC urin kelinci terhadap pertumbuhan tanaman sawi sendok, (2) pengaruh pupuk NPK terhadap pertumbuhan tanaman sawi sendok, (3) pengaruh kombinasi POC urin kelinci dan pupuk NPK terhadap pertumbuhan tanaman sawi sendok, (4) dosis POC urin kelinci dan pupuk NPK yang memberikan respon pertumbuhan tanaman sawi sendok terbaik.

\section{Bahan dan Metode}

\section{Waktu dan Tempat}

Penelitian ini telah dilaksanakan pada bulan Mei sampai dengan Juli 2020 di Greenhouse Udayana Jalan Gili Trawangan, Karang Baru, Kota Mataram. Parameter pertumbuhan yang diukur adalah tinggi tanaman, jumlah daun, luas daun, berat basah, berat kering dan kandungan klorofil total. Bahan-bahan yang digunakan dalam penelitian ini adalah air, tanah subur, sekam, pupuk NPK, benih sawi sendok, polibag ukuran 30x30 $\mathrm{cm}$, EM4, urin kelinci, gula merah, kertas label, aseton $80 \%$, kertas saring, dan kertas aluminium foil. Alat-alat yang digunakan dalam penelitian ini adalah sekop, digital tester meter, wadah, gelas ukur, tong plastik, oven, pengaduk kayu, pengayak tanah, penggaris, spektrofotometer, timbangan analitik, termometer, timbangan manual, cuvet, tabung reaksi, mortar dan pestle.

Tahap pelaksanaan penelitian ini adalah: (1) membuat POC dari urin kelinci yang difermentasikan selama 14 hari, (2) menyiapkan media tanam dengan mencampur sekam dan tanah dengan perbandingan volume $2: 1$, (3) menyeleksi benih yang baik, (3) menanam benih sebanyak 8 benih per polibag, (4) melakukan penjarangan setelah tanaman tumbuh dengan jumlah daun sebanyak 2 helai, (5) melakukan pemeliharaan dengan penyiraman dan penyiangan, (6) memberikan POC urin kelinci dan pupuk NPK sesuai dosis perlakuan dengan interval pemberian satu kali seminggu, (7) mengukur $\mathrm{pH}$ tanah dan suhu lingkungan, (8) mengukur parameter pertumbuhan tanaman.

$$
\text { Adapun teknik pengukuran }
$$


pertumbuhan tanaman sawi sendok sebagai berikut:

\section{Tinggi tanaman}

Tinggi tanaman diukur menggunakan penggaris, mulai dari pangkal batang yang paling dekat dengan akar hingga ujung daun terpanjang dinaikkan.

2. Jumlah daun Jumlah daun yang dihitung adalah daun yang telah membuka sempurna.

3. Luas daun

Pengukuran luas daun dilakukan dengan metode gravimetrik. Menurut Irwan \& Wicaksono (2017), luas daun dapat dihitung dengan menggunakan rumus:

Luas Daun $=\underline{\text { Bobot replika daun }} \times 100 \mathrm{~cm}^{2}$ Bobot kertas $10 \mathrm{~cm} \times 10 \mathrm{~cm}$

4. Berat basah

Tanaman dibersihkan dari tanah yang melekat menggunakan air mengalir, selanjutnya dikering anginkan selama 5 menit lalu ditimbang semua bagian tanaman kecuali akar.

5. Berat kering

Tanaman dibungkus terlebih dahulu menggunakan kertas alumunium foil kemudian di oven selama 48 jam pada suhu $70{ }^{\circ} \mathrm{C}$. Setelah di oven, sampel tersebut ditimbang menggunakan timbangan analitik.

6. Kandungan klorofil total

Ekstrak klorofil diukur absorbannya menggunakan spektrofotometer dengan panjang gelombang $645 \mathrm{~nm}$ dan $663 \mathrm{~nm}$ (Ratag et al., 2017).

Rancangan penelitian yang digunakan adalah rancangan acak lengkap terdiri atas 2 faktor yang masing - masing memiliki 4 taraf pemupukan dan diulang sebanyak 3 kali. Faktor pertama adalah dosis pupuk organik cair urin kelinci yaitu $\mathrm{A} 0=0$ $\mathrm{ml} / 100 \mathrm{ml}$ air, $\mathrm{A} 1=2 \mathrm{ml} / 100 \mathrm{ml}$ air, $\mathrm{A} 2=4 \mathrm{ml} / 100$ $\mathrm{ml}$ air dan $\mathrm{A} 3=6 \mathrm{ml} / 100 \mathrm{ml}$ air. Faktor kedua adalah dosis pupuk NPK $(15: 15: 15)$ yaitu $\mathrm{B} 0=0$ $\mathrm{gr} / 100 \mathrm{ml}$ air, B1 = 0,4 gr $/ 100 \mathrm{ml}$ air, B2 $=0,6$ gr/100 ml air dan $\mathrm{B} 3=0,8 \mathrm{gr} / 100 \mathrm{ml}$ air. Setiap kombinasi perlakuan sebagai berikut:
Tabel kombinasi Perlakuan

\begin{tabular}{|l|l|l|l|l|}
\hline Perlakuan & A0 & A1 & A2 & A3 \\
\hline B0 & A0B0 & A1B0 & A2B0 & A3B0 \\
\hline B1 & A0B1 & A1B1 & A2B1 & A3B1 \\
\hline B2 & A0B2 & A1B2 & A2B2 & A3B2 \\
\hline B3 & A0B3 & A1B3 & A2B3 & A3B3 \\
\hline
\end{tabular}

Data kuantitatif hasil pengukuran parameter pertumbuhan sawi sendok dianalisis menggunakan uji ANOVA (Analysis of Variance) dua arah. Uji lanjut yang digunakan adalah Duncan's Multiple Range Test (DMRT). Uji lanjut dapat dilakukan apabila nilai $p($ sig $)<0,05$ (Hanafiah, 2016). Analsis data dilakukan dengan bantuan aplikasi SPSS Statistic Versi 24. Hasil analisis uji ANOVA menunjukkan bahwa semua faktor utama dan faktor interaksi diperoleh nilai $\mathrm{p}$ (sig) $<0,05$. Hasil analisis tersebut dapat diketahui bahwa pengujian hipotesis alternatif (Ha) diterima pada taraf uji 5\%. Hal tersebut menandakan bahwa faktor utama POC urin kelinci, faktor utama pupuk NPK, faktor interaksi memberikan pengaruh yang signifikan terhadap semua parameter pertumbuhan sawi sendok yang diamati. Rekapitulasi uji ANOVA pengaruh utama dan interaksi POC urin kelinci dan pupuk NPK terhadap pertumbuhan sawi sendok disajikan pada Tabel 1.

\begin{tabular}{|c|c|c|c|c|}
\hline \multirow[b]{2}{*}{$\mathrm{N}_{0}$} & \multirow[b]{2}{*}{$\begin{array}{c}\text { Parameter } \\
\text { Pertumbuhan }\end{array}$} & \multicolumn{3}{|c|}{ Nilai P (Sig) } \\
\hline & & $\begin{array}{c}\text { POC } \\
\text { Urin } \\
\text { Kelinci }\end{array}$ & $\begin{array}{c}\text { Pupuk } \\
\text { NPK }\end{array}$ & $\begin{array}{c}\text { POC Urin } \\
\text { Kelinci*Pupuk } \\
\text { NPK }\end{array}$ \\
\hline 1 & Tinggi Tanaman & $0,000^{*}$ & $0,000^{*}$ & $0,005^{*}$ \\
\hline 2 & Jumlah Daun & $0,000^{*}$ & $0,000^{*}$ & $0,008^{*}$ \\
\hline 3 & Luas Daun & $0,000^{*}$ & $0,000^{*}$ & $0,001^{*}$ \\
\hline 4 & Berat Basah & $0,000^{*}$ & $0,000^{*}$ & $0,010^{*}$ \\
\hline 5 & Berat Kering & $0,000^{*}$ & $0,000^{*}$ & $0,015^{*}$ \\
\hline 6 & Klorofil Total & $0,000^{*}$ & $0,000^{*}$ & $0,011^{*}$ \\
\hline
\end{tabular}

\section{Hasil dan Pembahasan}

\section{Kondisi Lingkungan}

Faktor lingkungan tempat penelitian dapat mempengaruhi pertumbuhan sawi sendok. Pengukuran kondisi lingkungan dilakukan seminggu sekali selama 32 hari. Kondisi suhu lingkungan tempat penelitian disajikan pada gambar 1 . 


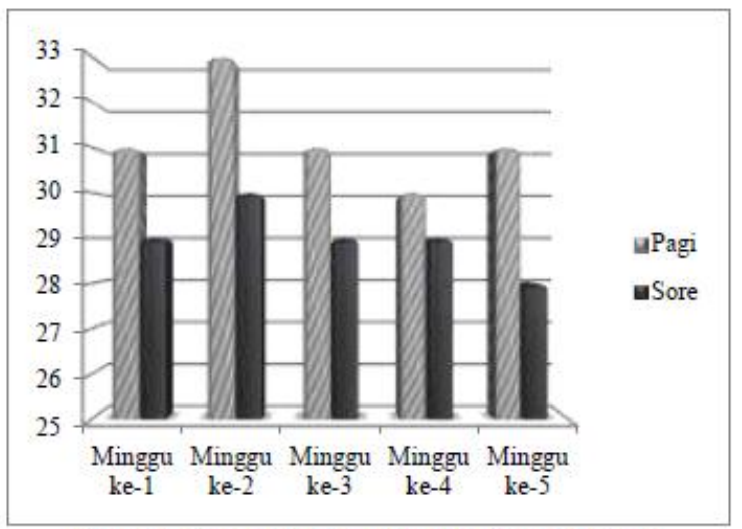

Gambar 1. Diagram Suhu Lingkungan Tempat Penelitian

Suhu lingkungan (0C) pada pagi hari lebih tinggi dibandingkan suhu lingkungan pada sore hari, dimana suhu lingkungan tempat penelitian pada pagi hari berkisar 300C - 330C. Sedangkan suhu lingkungan tempat penelitian pada sore hari berkisar 280C - 300C. Rata-rata kondisi pH tanah pada minggu pertama dan minggu kedua untuk semua perlakuan mencapai $\mathrm{pH}$ 6,5, sedangkan rata-rata $\mathrm{pH}$ tanah pada minggu ketiga sampai minggu kelima mengalami penurunan $\mathrm{pH}$ tanah kecuali pada perlakuan A0B0 (kontrol). Rata-rata $\mathrm{pH}$ tanah untuk perlakuan POC urin kelinci pada minggu ketiga sampai dengan minggu kelima berkisar $\mathrm{pH}$ 6,0 - 6,5 dan rata-rata $\mathrm{pH}$ tanah untuk perlakuan pupuk NPK berkisar $\mathrm{pH} 5,8$ - 6,5, sedangkan rata-rata kondisi $\mathrm{pH}$ tanah untuk perlakuan kombinasi POC urin kelinci dan pupuk NPK pada minggu ketiga sampai dengan minggu kelima mencapai pH 5,5-6,5.

\section{Tinggi Tanaman}

Pengukuran tinggi tanaman dilakukan dengan cara non-destruktif. Hasil pengukuran tinggi tanaman sawi sendok pada umur 32 HST akibat pemberian POC urin kelinci dan pupuk NPK disajikan pada Gambar 2 dan Gambar 3.

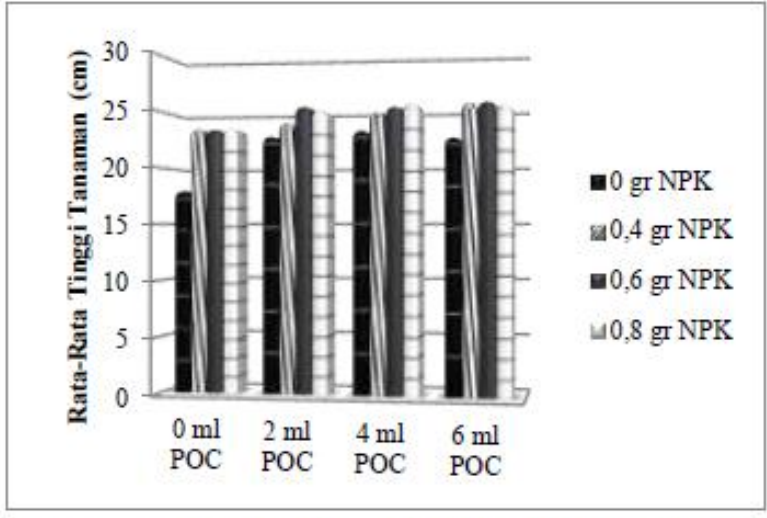

Gambar 2. Diagram Pengaruh Perlakuan POC Unin Kelinci dan Pupuk NPK terhadap Tinggi Tanaman Sawi Sendok

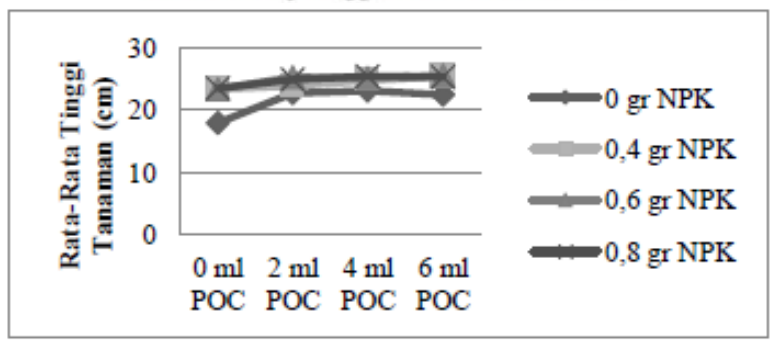

Gambar 3. Grafik Pengaruh Perlakuan POC Urin Kelinci dan Pupuk NPK terhadap Tinggi Tanaman Sawi Sendok

Gambar 2 dan Gambar 3 menunjukkan bahwa perlakuan yang memperoleh rata-rata tertinggi ditunjukkan pada perlakuan $6 \mathrm{ml} \mathrm{POC} / 100 \mathrm{ml}$ air dan 0,6 gram NPK/100 ml air yaitu $25,57 \mathrm{~cm}$, sedangkan ratarata terendah ditunjukkan pada perlakuan kontrol yaitu $17,93 \mathrm{~cm}$. Hasil uji perbedaan antar kombinasi terhadap tinggi tanaman sawi sendok disajikan pada Tabel 2.

\begin{tabular}{|c|c|c|}
\hline Kode & $\begin{array}{l}\text { Dosis Perlakuan } \\
\text { (per } 100 \mathrm{ml} \text { air) }\end{array}$ & $\begin{array}{c}\text { Rata-Rata Tinggi } \\
\text { Tanaman }(\mathrm{cm})\end{array}$ \\
\hline $\mathrm{A} 0 \mathrm{~B} 0$ & $0 \mathrm{ml} \mathrm{POC}+0$ gr NPK & 17,93 a \\
\hline $\mathrm{A} 1 \mathrm{~B} 0$ & $2 \mathrm{ml} \mathrm{POC}+0 \mathrm{gr}$ NPK & $22,73 \mathrm{~b}$ \\
\hline $\mathrm{A} 2 \mathrm{~B} 0$ & $4 \mathrm{ml} \mathrm{POC}+0$ gr NPK & $23,17 \mathrm{~b}$ \\
\hline $\mathrm{A} 3 \mathrm{~B} 0$ & $6 \mathrm{ml} \mathrm{POC}+0$ gr NPK & $22,50 \mathrm{~b}$ \\
\hline $\mathrm{A} 0 \mathrm{~B} 1$ & $0 \mathrm{ml} \mathrm{POC}+0,4$ gr NPK & $23,47 \mathrm{bc}$ \\
\hline $\mathrm{A} 0 \mathrm{~B} 2$ & $0 \mathrm{ml} \mathrm{POC}+0,6 \mathrm{gr} N \mathrm{~K}$ & $23,40 \mathrm{bc}$ \\
\hline $\mathrm{A} 0 \mathrm{~B} 3$ & $0 \mathrm{ml} \mathrm{POC}+0,8 \mathrm{gr}$ NPK & $23,50 \mathrm{bc}$ \\
\hline A1B1 & $2 \mathrm{ml} \mathrm{POC}+0,4 \mathrm{gr} N P K$ & $23,93 \mathrm{bcd}$ \\
\hline $\mathrm{A} 2 \mathrm{~B} 1$ & $4 \mathrm{ml} \mathrm{POC}+0,4 \mathrm{gr} N P K$ & 24,80 cde \\
\hline A3B1 & $6 \mathrm{ml} \mathrm{POC}+0,4 \mathrm{gr} N \mathrm{NP}$ & $25,50 \mathrm{de}$ \\
\hline A1B2 & $2 \mathrm{ml} \mathrm{POC}+0,6 \mathrm{gr} N \mathrm{NP}$ & 25,33 de \\
\hline $\mathrm{A} 2 \mathrm{~B} 2$ & $4 \mathrm{ml} \mathrm{POC}+0,6 \mathrm{gr} N \mathrm{NP}$ & 25,23 de \\
\hline A3B2 & $6 \mathrm{ml} \mathrm{POC}+0,6 \mathrm{gr}$ NPK & $25,57 \mathrm{e}$ \\
\hline A1B3 & $2 \mathrm{ml} \mathrm{POC}+0,8 \mathrm{gr}$ NPK & $25,00 \mathrm{de}$ \\
\hline $\mathrm{A} 2 \mathrm{~B} 3$ & $4 \mathrm{ml} \mathrm{POC}+0,8 \mathrm{gr}$ NPK & $25,47 \mathrm{de}$ \\
\hline A3B3 & $6 \mathrm{ml} \mathrm{POC}+0,8 \mathrm{gr}$ NPK & 25,33 de \\
\hline
\end{tabular}

Hasil uji DMRT 5\% pada Tabel 2 menunjukkan perlakuan A3B2 yang berbeda 
nyata dengan perlakuan lain merupakan dosis optimum terhadap tinggi tanaman, meskipun berbeda tidak nyata dengan perlakuan A2B1, A3B1, A1B2, A2B2, A1B3, A2B3 dan A3B3. Pengaruh perlakuan A3B2 bermutu lebih baik dibandingkan perlakuan yang berbeda tidak nyata lainnya terhadap tinggi tanaman.

\section{Jumlah Daun}

Perhitungan jumlah daun dilakukan dengan cara non-destruktif. Hasil pengukuran jumlah daun sawi sendok pada umur 32 HST akibat pemberian POC urin kelinci dan pupuk NPK disajikan pada Gambar 4 dan Gambar 5.

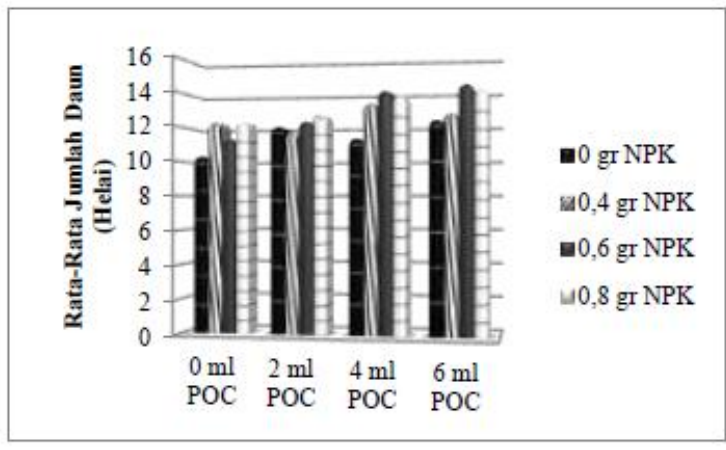

Gambar 4. Diagram Pengaruh Perlakuan POC Unin Kelinci dan Pupuk NPK terhadap Jumlah Daun Sawi Sendok

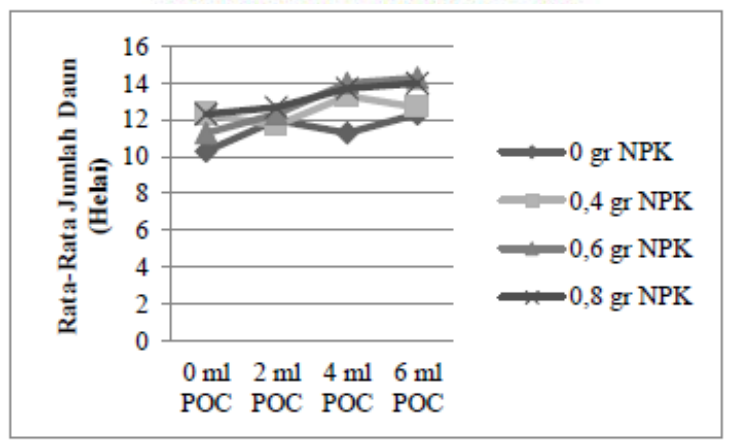

Gambar 5. Grafik Pengaruh Perlakuan POC Urin Kelinci dan Pupuk NPK terhadap Jumlah Daun Sawi Sendok

Gambar 4 dan Gambar 5 menunjukkan bahwa perlakuan yang memperoleh rata-rata tertinggi ditunjukkan pada perlakuan $6 \mathrm{ml} \mathrm{POC/100} \mathrm{ml} \mathrm{air}$ dan 0,6 gram NPK/100 ml air yaitu 14,3 helai, sedangkan ratarata terendah ditunjukkan pada perlakuan kontrol yaitu 10,3 helai. Hasil uji perbedaan antar kombinasi terhadap jumlah daun sawi sendok disajikan pada Tabel 3.
Tabel 3. Hasil Uji Perbedaan antar Kombinasi terhadap jumlah daun

\begin{tabular}{|c|c|c|}
\hline \multicolumn{3}{|c|}{ Sawi Sendok } \\
\hline Kode & $\begin{array}{c}\text { Dosis Perlakuan } \\
\text { (per } 100 \mathrm{ml} \text { air) }\end{array}$ & $\begin{array}{l}\text { Rata-Rata Jumlah } \\
\text { Daun (helai) }\end{array}$ \\
\hline A0B0 & $0 \mathrm{ml} \mathrm{POC}+0$ gr NPK & $10,3 \mathrm{a}$ \\
\hline A1B0 & $2 \mathrm{ml} \mathrm{POC}+0 \mathrm{gr} \mathrm{NPK}$ & $12,0 \mathrm{bc}$ \\
\hline $\mathrm{A} 2 \mathrm{~B} 0$ & $4 \mathrm{ml} \mathrm{POC}+0 \mathrm{gr} \mathrm{NPK}$ & $11,3 \mathrm{ab}$ \\
\hline $\mathrm{A} 3 \mathrm{~B} 0$ & $6 \mathrm{ml} \mathrm{POC}+0 \mathrm{gr}$ NPK & $12,3 \mathrm{bcd}$ \\
\hline $\mathrm{A} 0 \mathrm{~B} 1$ & $0 \mathrm{ml} \mathrm{POC}+0,4 \mathrm{gr} \mathrm{NPK}$ & $12,3 \mathrm{bcd}$ \\
\hline $\mathrm{A} 0 \mathrm{~B} 2$ & $0 \mathrm{ml} \mathrm{POC}+0,6 \mathrm{gr} \mathrm{NPK}$ & $11,3 \mathrm{ab}$ \\
\hline $\mathrm{A} 0 \mathrm{~B} 3$ & $0 \mathrm{ml} \mathrm{POC}+0,8 \mathrm{gr} \mathrm{NPK}$ & $12,3 \mathrm{bcd}$ \\
\hline A1B1 & $2 \mathrm{ml} \mathrm{POC}+0,4 \mathrm{gr} \mathrm{NPK}$ & $11,7 \mathrm{bc}$ \\
\hline A2B1 & $4 \mathrm{ml} \mathrm{POC}+0,4 \mathrm{gr} \mathrm{NPK}$ & $13,3 \mathrm{def}$ \\
\hline $\mathrm{A} 3 \mathrm{~B} 1$ & $6 \mathrm{ml} \mathrm{POC}+0,4 \mathrm{gr} \mathrm{NPK}$ & 12,7 cde \\
\hline A1B2 & $2 \mathrm{ml} \mathrm{POC}+0,6 \mathrm{gr} \mathrm{NPK}$ & $12,3 \mathrm{bcd}$ \\
\hline $\mathrm{A} 2 \mathrm{~B} 2$ & $4 \mathrm{ml} \mathrm{POC}+0,6 \mathrm{gr} \mathrm{NPK}$ & $14,0 \mathrm{f}$ \\
\hline A3B2 & $6 \mathrm{ml} \mathrm{POC}+0,6 \mathrm{gr} N P K$ & $14,3 \mathrm{f}$ \\
\hline A1B3 & $2 \mathrm{ml} \mathrm{POC}+0,8 \mathrm{gr} \mathrm{NPK}$ & 12,7 cde \\
\hline A2B3 & $4 \mathrm{ml} \mathrm{POC}+0,8 \mathrm{gr} \mathrm{NPK}$ & 13,7 ef \\
\hline A3B3 & $6 \mathrm{ml} \mathrm{POC}+0,8 \mathrm{gr} \mathrm{NPK}$ & $14,0 \mathrm{f}$ \\
\hline
\end{tabular}

Hasil uji DMRT 5\% pada Tabel 3 menunjukkan perlakuan A2B2, A3B2, A3B3 yang berbeda nyata dengan perlakuan lain merupakan dosis optimum terhadap jumlah daun sawi sendok, meskipun berbeda tidak nyata dengan perlakuan A2B1 dan A2B3. Pengaruh perlakuan A2B2 terhadap jumlah daun memiliki nilai yang sama besar dengan perlakuan dosis yang lebih tinggi.

\section{Luas Daun}

Perhitungan luas daun dilakukan dengan cara destruktif. Hasil pengukuran luas daun sawi sendok pada umur 32 HST akibat pemberian POC urin kelinci dan pupuk NPK disajikan pada Gambar 6 dan Gambar 7.

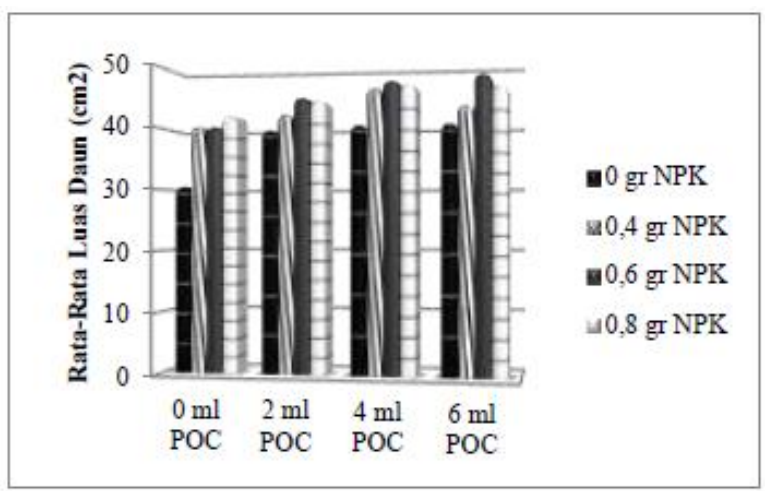

Gambar 6. Diagram Pengaruh Perlakuan POC Unin Kelinci dan Pupuk NPK terhadap Luas Daun Sawi Sendok 


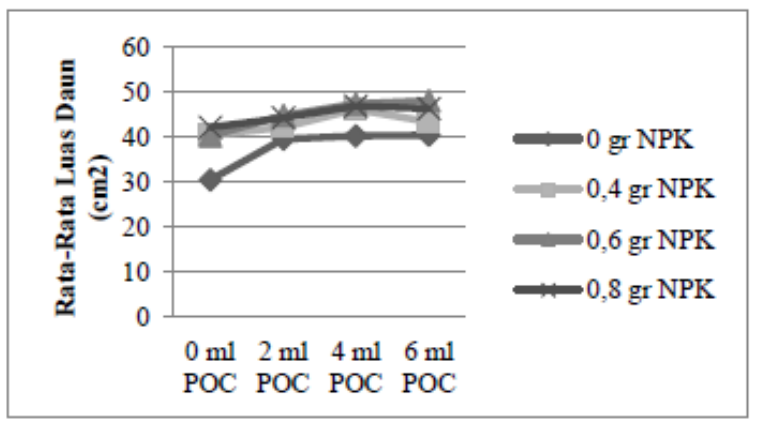

Gambar 7. Grafik Pengaruh Perlakuan POC Urin Kelinci dan Pupuk NPK terhadap Luas Daun Sawi Sendok

Gambar 6 dan Gambar 7 menunjukkan bahwa perlakuan yang memperoleh rata-rata tertinggi ditunjukkan pada perlakuan $6 \mathrm{ml} \mathrm{POC} / 100 \mathrm{ml}$ air dan 0,6 gr NPK/100 ml air yaitu 48,12 cm2, sedangkan rata-rata terendah ditunjukkan pada perlakuan kontrol yaitu 30,43 cm2. Hasil uji perbedaan antar kombinasi terhadap luas daun sawi sendok disajikan pada Tabel 4.

Tabel 4. Hasil Uji Perbedaan antar Kombinasi terhadap luas daun Sawi

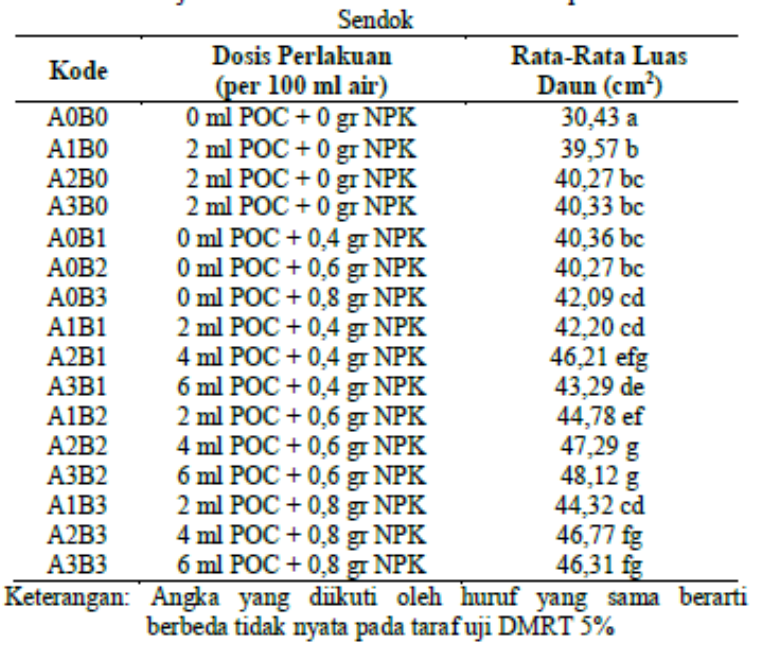

Hasil uji DMRT 5\% pada Tabel 4 menunjukkan perlakuan perlakuan A2B2 dan A3B2 yang berbeda nyata dengan perlakuan lain merupakan dosis optimum terhadap luas daun sawi sendok, meskipun berbeda tidak nyata dengan perlakuan A2B1, A2B3 dan A3B3. Pengaruh perlakuan A2B2 terhadap luas daun memiliki nilai yang sama besar dengan perlakuan dosis yang lebih tinggi.

\section{Berat Basah}

Pengukuran berat basah dilakukan dengan cara destruktif. Hasil pengukuran berat basah sawi sendok pada umur 32 HST akibat pemberian POC urin kelinci dan pupuk NPK disajikan pada
Gambar 8 dan Gambar 9.

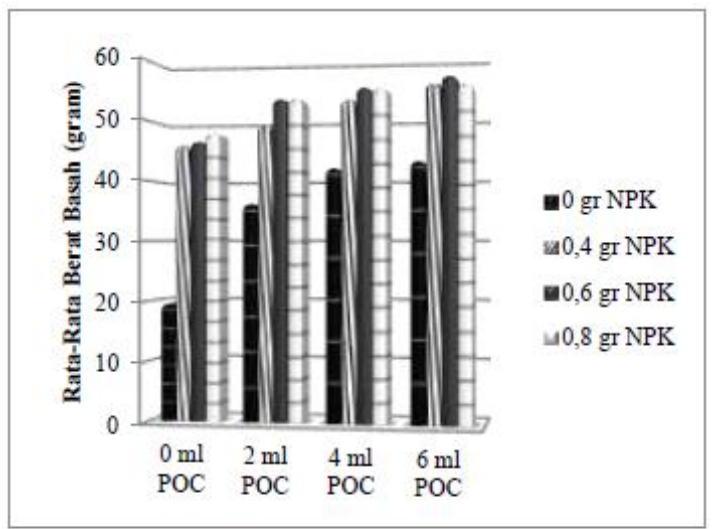

Gambar 8. Diagram Pengaruh Perlakuan POC Urin Kelinci dan Pupuk NPK terhadap berat basah Sawi Sendok

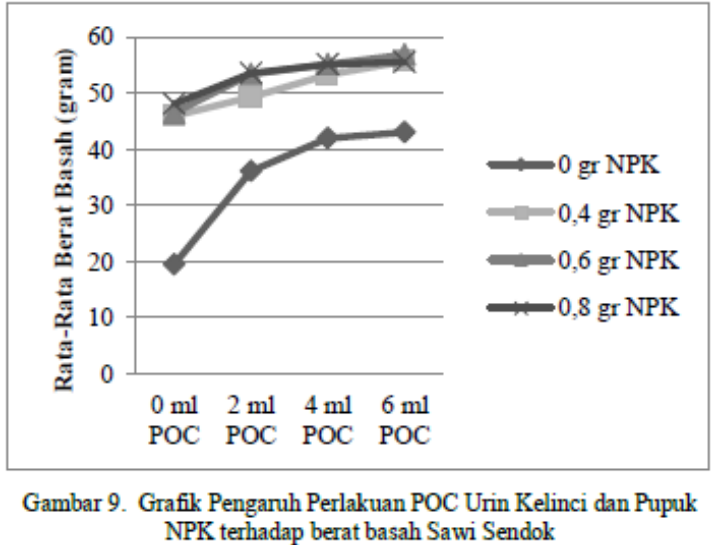

Gambar 8 dan Gambar 9 menunjukkan bahwa perlakuan yang memperoleh rata-rata tertinggi ditunjukkan pada perlakuan $6 \mathrm{ml} P O C / 100 \mathrm{ml}$ air dan 0,6 gr NPK/100 ml air yaitu 56,72 gram. Sedangkan rata-rata terendah ditunjukkan pada perlakuan kontrol yaitu 19,50 gram. Hasil uji perbedaan antar kombinasi terhadap berat basah sawi sendok disajikan pada Tabel 5.

Tabel 5. Hasil Uji Perbedaan antar Kombinasi terhadap Berat Basah
Sawi Sendok


Hasil uji DMRT 5\% pada Tabel 5 menunjukkan perlakuan A3B2 dan A2B3 yang berbeda nyata dengan perlakuan lain merupakan dosis optimum terhadap berat basah tanaman, meskipun berbeda tidak nyata dengan perlakuan A2B1, A3B1, A1B2, A2B2, A1B3, dan A3B3. Pengaruh perlakuan A3B2 terhadap berat basah memiliki nilai yang sama besar dengan perlakuan dosis yang lebih tinggi.

\section{Berat Kering}

Pengukuran berat kering dilakukan dengan cara destruktif. Hasil pengukuran berat kering sawi sendok pada umur 32 HST akibat pemberian POC urin kelinci dan pupuk NPK disajikan pada Gambar 10 dan Gambar 11.

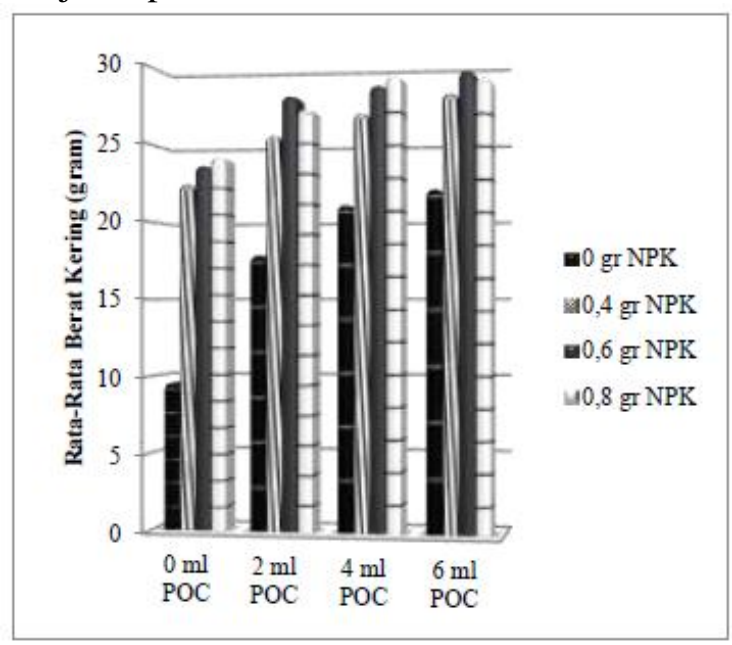

Gambar 10. Diagram Pengaruh Perlakuan POC Unin Kelinci dan Pupuk NPK terhadap berat kering Sawi Sendok

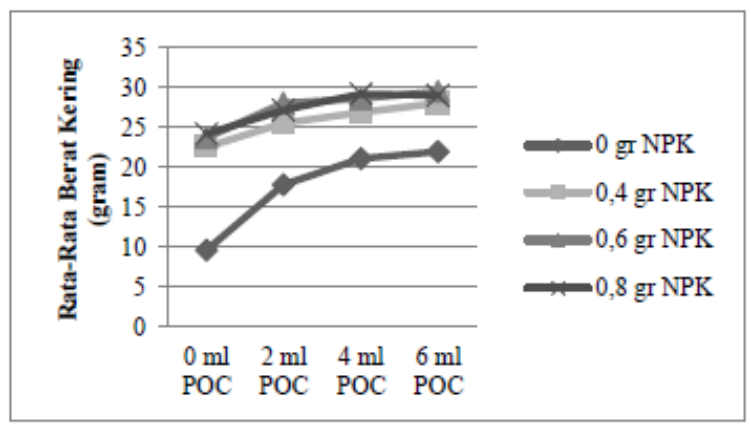

Gambar 11. Grafik Pengaruh Perlakuan POC Urin Kelinci dan Pupuk NPK terhadap berat kering Sawi Sendok
Gambar 10 dan Gambar 11 menunjukkan bahwa perlakuan yang memperoleh rata-rata tertinggi ditunjukkan pada perlakuan $6 \mathrm{ml} P O C / 100 \mathrm{ml}$ air dan 0,6 gr NPK/100 ml air yaitu 29,40 gram. Sedangkan ratarata terendah ditunjukkan pada perlakuan kontrol yaitu 9,56 gram. Hasil uji perbedaan antar kombinasi terhadap berat kering sawi sendok disajikan pada Tabel 6.

Tabel 6. Hasil Uji Perbedaan antar Kombinasi terhadap Berat Kering Sawi Sendok

\begin{tabular}{|c|c|c|}
\hline Kode & $\begin{array}{l}\text { Dosis Perlakuan } \\
\text { (per } 100 \mathrm{ml} \text { air) }\end{array}$ & $\begin{array}{c}\text { Rata-Rata Berat } \\
\text { Kering (gr) }\end{array}$ \\
\hline $\mathrm{A} 0 \mathrm{~B} 0$ & $0 \mathrm{ml} \mathrm{POC}+0$ gr NPK & $9,56 \mathrm{a}$ \\
\hline A1B0 & $2 \mathrm{ml} \mathrm{POC}+0 \mathrm{gr} \mathrm{NPK}$ & $17,81 \mathrm{~b}$ \\
\hline $\mathrm{A} 2 \mathrm{~B} 0$ & $2 \mathrm{ml} \mathrm{POC}+0 \mathrm{gr} \mathrm{NPK}$ & $21,02 \mathrm{c}$ \\
\hline $\mathrm{A} 3 \mathrm{~B} 0$ & $2 \mathrm{ml} \mathrm{POC}+0 \mathrm{gr} \mathrm{NPK}$ & $21,96 \mathrm{~cd}$ \\
\hline $\mathrm{A} 0 \mathrm{~B} 1$ & $0 \mathrm{ml} \mathrm{POC}+0,4 \mathrm{gr} \mathrm{NPK}$ & 22,47 cde \\
\hline $\mathrm{A} 0 \mathrm{~B} 2$ & $0 \mathrm{ml} \mathrm{POC}+0,6 \mathrm{gr} \mathrm{NPK}$ & 23,62 cde \\
\hline $\mathrm{A} 0 \mathrm{~B} 3$ & $0 \mathrm{ml} \mathrm{POC}+0,8 \mathrm{gr} \mathrm{NPK}$ & 24,17 def \\
\hline A1B1 & $2 \mathrm{ml} \mathrm{POC}+0,4 \mathrm{gr} \mathrm{NPK}$ & $25,52 \mathrm{efg}$ \\
\hline $\mathrm{A} 2 \mathrm{~B} 1$ & $4 \mathrm{ml} \mathrm{POC}+0,4 \mathrm{gr} N P K$ & $26,86 \mathrm{fgh}$ \\
\hline A3B1 & $6 \mathrm{ml} \mathrm{POC}+0,4 \mathrm{gr} N P K$ & $28,03 \mathrm{gh}$ \\
\hline A1B2 & $2 \mathrm{ml} \mathrm{POC}+0,6$ gr NPK & $28,02 \mathrm{gh}$ \\
\hline $\mathrm{A} 2 \mathrm{~B} 2$ & $4 \mathrm{ml} \mathrm{POC}+0,6$ gr NPK & $28,58 \mathrm{gh}$ \\
\hline A3B2 & $6 \mathrm{ml} \mathrm{POC}+0,6 \mathrm{gr} \mathrm{NPK}$ & $29,40 \mathrm{~h}$ \\
\hline A1B3 & $2 \mathrm{ml} \mathrm{POC}+0,8 \mathrm{gr} \mathrm{NPK}$ & $27,16 \mathrm{fgh}$ \\
\hline $\mathrm{A} 2 \mathrm{~B} 3$ & $4 \mathrm{ml} \mathrm{POC}+0,8 \mathrm{gr}$ NPK & $29,19 \mathrm{~h}$ \\
\hline A3B3 & $6 \mathrm{ml} \mathrm{POC}+0,8 \mathrm{gr} \mathrm{NPK}$ & $29,00 \mathrm{~h}$ \\
\hline & $\begin{array}{l}\text { ka yang diikuti oleh } \\
\text { eda tidak nyata pada tara }\end{array}$ & $\begin{array}{l}\text { ing sama } \\
\text { T } 5 \%\end{array}$ \\
\hline
\end{tabular}

Hasil uji DMRT 5\% pada Tabel 6 menunjukkan perlakuan A3B2, A2B3 dan A3B3 yang berbeda nyata dengan perlakuan lain merupakan dosis optimum terhadap berat kering tanaman meskipun berbeda tidak nyata dengan perlakuan A2B1, A3B1, A1B2, A2B2, dan A1B3. Pengaruh perlakuan A2B2 terhadap berat kering memiliki nilai yang sama besar dengan perlakuan dosis yang lebih tinggi.

\section{Kandungan Klorofil}

Pengukuran kandungan klorofil total dilakukan dengan cara destruktif. Hasil pengukuran klorofil total sawi sendok pada umur 32 HST akibat pemberian POC urin kelinci dan pupuk NPK disajikan pada Gambar 12 dan Gambar 13. 


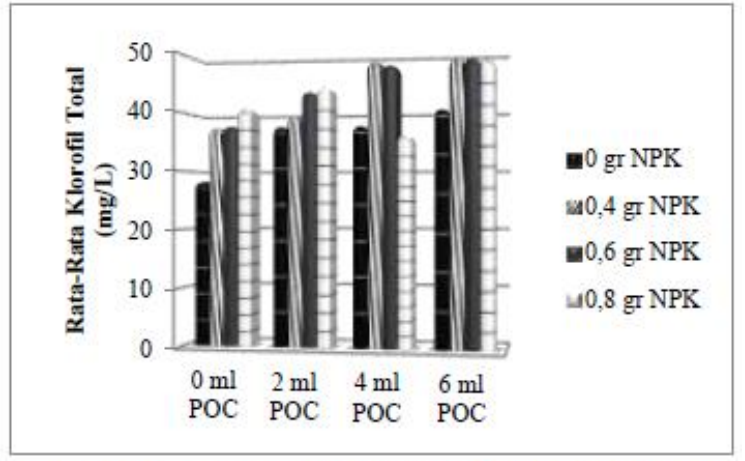

Gambar 12. Diagram Pengaruh Perlakuan POC Urin Kelinci dan Pupuk NPK terhadap Klorofil Total Sawi Sendok

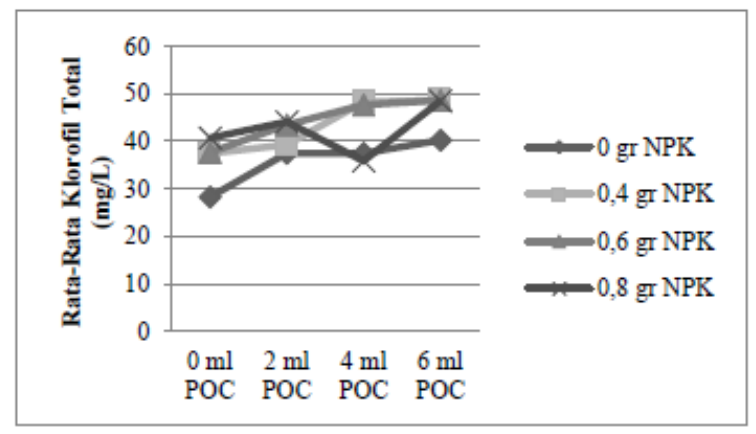

Gambar 13. Grafilk Pengaruh Perlakuan POC Unin Kelinci dan Pupulk NPK terhadap Klorofil Total Sawi Sendok

Gambar 12 dan Gambar 13 menunjukkan bahwa perlakuan yang memperoleh rata-rata tertinggi ditunjukkan pada perlakuan $6 \mathrm{ml}$ POC/100 ml air dan 0,6 gr NPK/100 ml air yaitu 48,62 mg/L. Sedangkan ratarata terendah ditunjukkan pada perlakuan kontrol yaitu 32,19 $\mathrm{mg} / \mathrm{L}$. Hasil uji perbedaan antar kombinasi terhadap kandungan klorofil total sawi sendok disajikan pada Tabel 7.

Tabel 7. Hasil Uji Perbedaan antar Kombinasi terhadap Kandungan Klorofil Total Sawi Sendok

\begin{tabular}{|c|c|c|}
\hline Kode & $\begin{array}{l}\text { Dosis Perlakuan } \\
\text { (per } 100 \mathrm{ml} \text { air) }\end{array}$ & $\begin{array}{l}\text { Rata-Rata Kandungan } \\
\text { Klorofil Total (mg/L) }\end{array}$ \\
\hline A0B0 & $0 \mathrm{ml} \mathrm{POC}+0$ gr NPK & 32,19 a \\
\hline A1B0 & $2 \mathrm{ml} \mathrm{POC}+0$ gr NPK & 38,00 abcd \\
\hline $\mathrm{A} 2 \mathrm{~B} 0$ & $2 \mathrm{ml} \mathrm{POC}+0$ gr NPK & 37,77 abcd \\
\hline $\mathrm{A} 3 \mathrm{~B} 0$ & $2 \mathrm{ml} \mathrm{POC}+0$ gr NPK & $40,50 \mathrm{bcd}$ \\
\hline $\mathrm{A} 0 \mathrm{~B} 1$ & $0 \mathrm{ml} \mathrm{POC}+0,4 \mathrm{gr} \mathrm{NPK}$ & $40,34 \mathrm{bcd}$ \\
\hline $\mathrm{A} 0 \mathrm{~B} 2$ & $0 \mathrm{ml} \mathrm{POC}+0,6 \mathrm{gr} \mathrm{NPK}$ & $33,29 \mathrm{ab}$ \\
\hline $\mathrm{A} 0 \mathrm{~B} 3$ & $0 \mathrm{ml} \mathrm{POC}+0,8 \mathrm{gr}$ NPK & 38,29 abcd \\
\hline A1B1 & $2 \mathrm{ml} \mathrm{POC}+0,4 \mathrm{gr} N P K$ & 39,21 abcd \\
\hline $\mathrm{A} 2 \mathrm{~B} 1$ & $4 \mathrm{ml} \mathrm{POC}+0,4 \mathrm{gr} \mathrm{NPK}$ & $48,32 \mathrm{e}$ \\
\hline A3B1 & $6 \mathrm{ml} \mathrm{POC}+0,4 \mathrm{gr} N P K$ & $48,61 \mathrm{e}$ \\
\hline A1B2 & $2 \mathrm{ml} \mathrm{POC}+0,6 \mathrm{gr} \mathrm{NPK}$ & 43,35 cde \\
\hline $\mathrm{A} 2 \mathrm{~B} 2$ & $4 \mathrm{ml} \mathrm{POC}+0,6 \mathrm{gr} \mathrm{NPK}$ & $47,68 \mathrm{e}$ \\
\hline A3B2 & $6 \mathrm{ml} \mathrm{POC}+0,6 \mathrm{gr}$ NPK & $48,62 \mathrm{e}$ \\
\hline A1B3 & $2 \mathrm{ml} \mathrm{POC}+0,8 \mathrm{gr} \mathrm{NPK}$ & $44,07 \mathrm{de}$ \\
\hline $\mathrm{A} 2 \mathrm{~B} 3$ & $4 \mathrm{ml} \mathrm{POC}+0,8 \mathrm{gr} \mathrm{NPK}$ & $35,77 \mathrm{abc}$ \\
\hline A3B3 & $6 \mathrm{ml} \mathrm{POC}+0,8 \mathrm{gr} \mathrm{NPK}$ & $48,46 \mathrm{e}$ \\
\hline Keterangan: & \multicolumn{2}{|c|}{$\begin{array}{l}\text { Angka yang diikuti oleh huruf yang sama berarti } \\
\text { berbeda tidak nyata pada taraf uji DMRT } 5 \%\end{array}$} \\
\hline & sil uji DMRT & $5 \%$ pada Tabel 7 \\
\hline
\end{tabular}

A3B2 dan A3B3 yang berbeda nyata dengan perlakuan lain merupakan dosis optimum terhadap klorofil total tanaman, meskipun berbeda tidak nyata dengan perlakuan A1B2 dan A1B3. Pengaruh perlakuan A2B1 terhadap klorofil total memiliki nilai yang sama besar dengan perlakuan dosis yang lebih tinggi.

\section{Pembahasan}

Pertumbuhan sawi sendok sangat dipengaruhi oleh ketersediaan unsur hara yang ditunjukkan dari hasil pemberian dosis POC urin kelinci dan pupuk NPK. Pupuk NPK yang digunakan mengandung unsur hara makro yang tinggi yaitu N (15\%), P (15\%) dan K (15\%). Hasil uji kandungan POC menunjukkan bahwa POC urin kelinci mengandung unsur hara $\mathrm{N}(0,11 \%), \mathrm{P}$ $(0,04 \%)$ dan K $(3,12 \%)$. Menurut Peraturan Menteri Pertanian Republik Indonesia Nomor 70 Tahun 2011, standar mutu untuk pupuk organik cair harus mengandung unsur $\mathrm{N}, \mathrm{P}, \mathrm{K}$ masingmasing 3-6\%. Hasil ini menunjukkan bahwa POC urin kelinci memiliki kandungan $\mathrm{K}$ sesuai kriteria mutu yang ditetapkan, sedangkan kandungan $\mathrm{N}$ dan $\mathrm{P}$ masih perlu dilakukan peningkatan melalui penambahan variasi bahan baku yang dapat menunjang peningkatan kadar unsur hara.

Pemberian pupuk NPK dapat memasok hara tertentu berupa senyawa anorganik berkonsentarasi tinggi dan responnya lebih cepat terlihat pada tanaman (Rinsema, 1983). Namun, pemupukan dengan pupuk NPK terus-menerus tanpa ada pemberian bahan organic menyebabkan akumulasi kandungan mineral dalam tanah dapat membunuh mikroorganisme yang bertugas melakukan dekomposisi tanah. Akibatnya, tanah menjadi keras serta kurang mampu menahan air dan nutrisi (Mulyani, 2014). Pupuk organik tidak mengandung unsur hara dalam jumlah yang besar tetapi penambahan bahan organik kedalam tanah dapat memicu pertumbuhan mikroorganisme yang membantu dalam penyerapan unsur hara dan berperan memperbaiki struktur tanah (Rinsema, 1983; Wahid et al, 2015).

Hasil uji ANOVA pada perlakuan kombinasi POC urin kelinci dan pupuk NPK menunjukkan adanya interaksi yang saling mendukung kinerja kedua faktor sehingga dapat meningkatkan semua parameter pertumbuhan sawi sendok (Tabel 1). Hal ini dikarenakan pemberian POC urin kelinci mampu 
meningkatkan serapan unsur hara pupuk NPK pada dosis yang diberikan (Susantidiana \& Aguzaen, 2015; Kristanto \& Aziz, 2019). Perlakuan kombinasi $6 \mathrm{ml} \mathrm{POC/100} \mathrm{ml} \mathrm{air} \mathrm{dan} \mathrm{0,6}$ gram NPK/100 $\mathrm{ml}$ air diperoleh rata-rata pertumbuhan sawi sendok tertinggi dibandingkan perlakuan lainnya. Hal ini sejalan dengan pernyataan Kurniawati et al (2015), bahwa pemberian pupuk organic yang dikombinasikan dengan pupuk anorganik dapat meningkatkan pertumbuhan tanaman dan membantu meningkatkan efisiensi penggunaan pupuk. Perlakuan kontrol diperoleh rata-rata pertumbuhan sawi sendok terendah. Hal ini dikarenakan tanaman hanya mengandalkan unsur hara pada media tanam sehingga terjadi kekurangan unsur hara yang dibutuhkan untuk pertumbuhannya. Kekurangan unsur hara esensial menyebabkan gangguan fisiologis sehingga tanaman tidak dapat tumbuh secara optimal (Kholidin et al, 2016).

Pemberian dosis pupuk sampai batas tertentu akan menyebabkan pertumbuhan tanaman semakin meningkat, namun pemberian dosis yang melebihi batas tertentu akan menyebabkan pertumbuhan tanaman menurun (Rusmawarni et al, 2016; Nuryani et al, 2019). Hal ini diduga bahwa pemberian dosis pupuk NPK yang tinggi dapat mengakibatkan larutan tanah menjadi pekat sehingga air dan mineral sulit diserap oleh akar tanaman (Rusmawarni et al, 2016). Hasil penelitian menunjukkan bahwa perlakuan kombinasi POC urin kelinci dengan pupuk NPK 0,8 gram mengalami penurunan rata-rata yang tidak signifikan dari perlakuan yang menunjukkan rata-rata pertumbuhan tanaman tertinggi. Pemberian pupuk kimia dalam jumlah yang berlebih akan menekan laju pertumbuhan tanaman, sebagaimana ditunjukkan pada tanaman jagung dengan kombinasi pupuk kascing 4 ton/ha dan NPK $300 \mathrm{~kg} / \mathrm{ha}$ menunjukkan tinggi tanaman, umur panen, lingkar tongkol dan berat tongkol jagung yang lebih rendah dibandingkan dengan pupuk kascing 4 ton/ha dan NPK $250 \mathrm{~kg} / \mathrm{ha}$ (Dailami et al, 2015).

Ketersediaan unsur $\mathrm{N}$ akan mendukung pertambahan tinggi tanaman karena unsur hara tersebut berperan dalam proses pembelahan dan pemanjangan sel (Erawan et al, 2013; Sarif et al, 2015; Fauzi et al, 2019). Besarnya unsur hara $\mathrm{N}$ yang diserap akan mempengaruhi jumlah bahan organik dan mineral yang akan ditranslokasikan untuk pembentukan daun yang akhirnya akan meningkatkan jumlah daun. Ketersediaan unsur N yang cukup tinggi dapat menghasilkan daun yang lebih besar karena unsur $\mathrm{N}$ merupakan komponen penyusun klorofil yang bertanggung jawab dalam proses fotosintesis, sehingga sebagian besar hasil fotosintesis tersebut dialihkan untuk proses perluasan daun (Rosdiana, 2015; Istarofah \& Salamah, 2017). Semakin tinggi pemberian N (sampai batas optimumnya) maka jumlah klorofil yang terbentuk akan meningkat (Pramitasari et al, 2016). Selain itu, adanya unsur $P$ yang diserap tanaman memberikan kontribusi dalam asimilasi dan membantu pembelahan sel serta perkembangan jaringan meristematik sehingga berpengaruh untuk pembentukan bakal daun serta membantu memperluas ukuran daun. Unsur hara $\mathrm{K}$ juga berperan sebagai pengaktif dari sejumlah enzim penting dalam proses fotosintesis dan respirasi serta dapat memacu titik-titik tumbuh tanaman (Wenno \& Sinay, 2019).

Peningkatan berat basah tanaman berkaitan dengan tinggi tanaman, jumlah dan luas daun. Semakin tinggi tanaman maka semakin banyak pula jumlah daunnya karena semakin banyak ruas batang yang akan menjadi tempat keluarnya daun. Semakin banyak jumlah daun maka mobilisasi menjadi lebih lancar sehingga terjadi pembentukan karbohidrat dari hasil fotosintesis yang menyebabkan pertambahan luas daun, dengan demikian akan mempengaruhi berat basah tanaman (Wijayanti et al, 2019). Peningkatan berat kering tanaman berkaitan dengan perkembangan daun dan metabolisme tanaman. Tanaman yang memiliki daun lebih luas dapat menyerap sinar matahari dengan efektif sehingga menghasilkan fotosintat lebih banyak karena dapat melakukan fotosintesis dengan baik (Darmawan et al, 2013; Simanullang et al, 2019). Pengaruh perlakuan terbaik ditunjukkan pada perlakuan dosis yang lebih rendah tetapi memiliki pengaruh yang sama besar dengan perlakuan dosis yang lebih tinggi dalam meningkatkan pertumbuhan tanaman sawi sendok (Hanafiah, 2016). Hasil uji DMRT 5\% menunjukkan bahwa perlakuan terbaik terhadap tinggi tanaman, berat basah dan berat kering adalah perlakuan $6 \mathrm{ml}$ POC/100 ml air dan 0,6 gram NPK/100 ml air. Perlakuan terbaik terhadap jumlah daun dan luas daun adalah perlakuan $4 \mathrm{ml}$ POC/100 $\mathrm{ml}$ air dan 
0,6 gram NPK/100 ml air, serta perlakuan terbaik terhadap kandungan klorofil total adalah dosis 4 $\mathrm{ml} \mathrm{POC/100} \mathrm{ml} \mathrm{air} \mathrm{dan} \mathrm{0,4} \mathrm{gram} \mathrm{NPK/100} \mathrm{ml} \mathrm{air,}$ sehingga secara ekonomi lebih efisien dalam meningkatkan pertumbuhan sawi sendok.

Faktor lingkungan seperti $\mathrm{pH}$ tanah dapat mempengaruhi pertumbuhan sawi sendok. Kondisi $\mathrm{pH}$ tanah yang optimum untuk pertumbuhan sawi sendok berkisar $\mathrm{pH}$ 5,5-7,0 (Myers, 1998). Hal ini sesuai dengan hasil pengukuran $\mathrm{pH}$ tanah selama 5 minggu pengamatan yang berkisar $\mathrm{pH}$ 5,5- 6,5. Suhu lingkungan juga berpengaruh terhadap pertumbuhan tanaman sawi sendok karena secara langsung akan mempengaruhi proses fotosintesis, respirasi dan transpirasi (Gustia, 2013; Rosdiana, 2015). Menurut Haryanto et al (2007), tanaman sawi sendok dapat tumbuh dengan baik pada suhu $27^{\circ} \mathrm{C}-32^{\circ} \mathrm{C}$, hal ini sesuai dengan hasil pengukuran suhu lingkungan tempat penelitian yang masih tergolong dalam kondisi optimal yaitu sekitar $28^{\circ} \mathrm{C}-33^{\circ} \mathrm{C}$ (Gambar 1). Suhu $33^{\circ} \mathrm{C}$ pada minggu kedua mengakibatkan kadar air dalam jaringan dan kadar air dalam tanah menurun karena tingginya laju transpirasi, namun suhu kembali optimal pada minggu berikutnya sehingga proses transpirasi pada tanaman dapat berlangsung normal (Anni et al, 2013).

Hasil penelitian ini sejalan dengan beberapa hasil penelitian lain. Pemberian kombinasi POC urin kelinci dan pupuk anorganik berpengaruh nyata pada tinggi tanaman dan luas daun tanaman jagung, tetapi tidak berpengaruh nyata pada jumlah daun, umur berbunga, jumlah tongkol, panjang tongkol, diameter tongkol dan berat tongkol tanaman jagung. (Fitriasari \& Rahmayuni, 2017). Pemberian kombinasi pupuk urin kelinci dengan pupuk NPK berpengaruh terhadap sifat Agro-morfologis tanaman tomat (Indabo \& Abubakar, 2020). Pengaruh kombinasi POC urin kelinci dan pupuk NPK menunjukkan hasil yang berbeda dengan hasil penelitian lain. Perlakuan kombinasi biourin kelinci dengan pupuk NPK tidak terjadi interaksi nyata terhadap pertumbuhan dan hasil panen tanaman jagung manis. Secara terpisah perlakuan biourin kelinci dan perlakuan pupuk NPK memberikan pengaruh nyata terhadap pertumbuhan dan hasil panen tanaman jagung manis (Sirot et al, 2017). Perbedaan penelitian yang dilakukan dengan penelitian relevan tersebut yaitu lokasi, rancangan penelitian dan dosis pupuk yang digunakan, selain itu jenis tanaman yang digunakan juga berbeda sehingga parameter pertumbuhan yang diamati berbeda pula. Pemupukan dengan POC urin kelinci, pemupukan dengan NPK maupun pemupukan dengan kombinasi POC dan NPK dapat meningkatkan pertumbuhan tanaman sawi sendok. Berdasarkan uraian diatas, penggunaan POC urin kelinci dan pupuk NPK dapat diaplikasikan secara terpisah maupun digunakan bersama. Namun penggunaan kedua pupuk secara bersama lebih direkomendasikan untuk mendapatkan pertumbuhan sawi sendok yang optimal. Hal tersebut menandakan bahwa pemberian kombinasi POC urin kelinci dengan pupuk NPK pada budidaya tanaman sawi sendok berpotensi mengurangi ketergantungan terhadap penggunaan pupuk anorganik.

\section{Kesimpulan}

Berdasarkan hasil penelitian dan pembahasan, maka dapat disimpulkan bahwa: (1) Pemberian POC urin kelinci dapat meningkatkan seluruh parameter pertumbuhan sawi sendok, (2) Pemberian pupuk NPK dapat meningkatkan seluruh parameter pertumbuhan sawi sendok, (3) Pemberian kombinasi POC urin kelinci dan pupuk NPK memiliki interaksi nyata terhadap seluruh parameter pertumbuhan sawi sendok, (4) Perlakuan terbaik terhadap tinggi tanaman, berat basah dan berat kering adalah dosis $6 \mathrm{ml} \mathrm{POC/100}$ $\mathrm{ml}$ air dan 0,4 gram NPK/100 ml air, perlakuan terbaik terhadap jumlah daun dan luas daun adalah dosis $4 \mathrm{ml} \mathrm{POC/100} \mathrm{ml} \mathrm{air} \mathrm{dan} \mathrm{0,6} \mathrm{gram} \mathrm{NPK/100}$ $\mathrm{ml}$ air, dan perlakuan terbaik terhadap kandungan klorofil total adalah dosis $4 \mathrm{ml} \mathrm{POC} / 100 \mathrm{ml}$ air dan 0,4 gram NPK/100 ml air.

\section{Ucapan Terima Kasih}

Penulis mengucapkan terima kasih kepada semua pihak yang telah membantu baik moril maupun materil sehingga terselesaikannya penelitian dan paper ini.

\section{Referensi}

Anni, I., A., Septianingsih, E., \& Haryanti, S. (2013). Pengaruh Naungan terhadap Pertumbuhan dan Produksi Tanaman Bawang Daun (Allium fistulosum L.) di 
Bendungan, Jawa Tengah. Jurnal Biologi, 2(3), 31-40. https://ejournal3.undip.ac.id/index.php/biol ogi/article/view/19151/18184.

Dailami, A., Yetti, H., \& Yoseva, S. (2015). Pengaruh Pemberian Pupuk Kascing dan NPK terhadap Pertumbuhan dan Produksi Tanaman Jagung Manis (Zea mays Var saccharata Sturt). Jurnal JOM Faperta, 2(2),

$1-12$.

https://jom.unri.ac.id/index.php/JOMFAPE RTA/article/view/8359/8028.

Darmawan, A.F., Herlina, N., \& Soelistyono, R. (2013). Pengaruh berbagai Macam Bahan Organik dan Pemberian Air terhadap Pertumbuhan dan Hasil Tanaman Sawi (Brassica juncea L.). Jurnal Produksi Tanaman, 1(5), 389-397. https://media.neliti.com/media/publications /126573-ID-none.pdf.

Dewanto, F. G., Londok, J.J.M.R., \& Tuturoong, R.A.V. (2013). Pengaruh Pemupukan Anorganik dan Organik Terhadap Produksi Tanaman Jagung Sebagai Sumber Pakan. Jurnal Zootek, 32(5), 1-8. https://doi.org/10.35792/zot.32.5.2013.982

Erawan, D., Yani, W. O., \& Bahrun, A. (2013). Pertumbuhan dan Hasil Tanaman Sawi (Brassica juncea L.) pada Berbagai Dosis Pupuk Urea. Jurnal Agroteknos, 3(1), 1925.

http://faperta.uho.ac.id/agroteknos/Daftar Jurnal/2013/2013-1-04-

DEDI\%20ERAWAN.pdf.

Fauzi, A. R., Casdi, \& Warid. (2019). Respon Tanaman Pakcoy (Brassica rapa L.) terhadap Pemberian Pupuk Organik Cair Limbah Perikanan. Jurnal Hort. Indonesia, 10(2),

94-101. http://dx.doi.org/10.29244/jhi.10.2.94-101.

Fitriasari, C., \& Rahmayani, E. (2017). Efektivitas Pemberian Urin Kelinci untuk Mengurangi Dosis Pupuk Anorganik pada Budidaya Putren Jagung Manis. Jurnal Agrosains dan
Teknologi, 2(2), 141-156. https://doi.org/10.24853/jat.2.2.141\%20\% E2\%80\%93\%20156.

Gustia, H. (2013). Pengaruh Penambahan Sekam Bakar pada Media Tanam terhadap Pertumbuhan dan Produksi Tanaman Sawi (Brassica juncea L.). EJournal Widya Kesehatan dan Lingkungan, 1(1), 12-17. https://media.neliti.com/media/publications 136807-ID-pengaruhpenambahan-sekambakar-padamedia-tanam terhadappertumbuhan-danproduks.pdf.

Hanafiah, K. A. (2016). Rancangan Percobaan Teori dan Aplikasi (Ed. Ketiga). Jakarta: PT. Raja Grafindo Persada.

Hartini, S., Sholihah, S. M., \& Manshur, E. (2019). Pengaruh Konsentrasi Urin Kelinci Terhadap Pertumbuhan dan Hasil Bayam Merah (Amaranthus gangeticus voss). Jurnal Ilmiah Respati, 10(1), 20-27. http://ejournal.urindo.ac.id/index.php/perta nian/article/viewFile/355/306.

Haryanto, E., Suhartini, T., \& Rahayu, E. (2007). Sawi \& Selada. Jakarta: Penebar Swadaya.

Indabo, S. S., \& Abubakar, A. A. (2020). Effect of Rabbit Urine Application Rate as a BioFertilizer on Agro Morphorlogical Traits of UC82B Tomato (Lycopersicum esculentum Mill) Variety in Zaria, Nigeria. Dutse Journal of Pure and Applied Sciences (DUJOPAS), 6(2), 344-352. https://www.researchgate.net/publication/3 42513142_Effect_of_Rabbit_Urine_Appli cation_Rate_as_a_Bio_Fertilizer_on_Agro -

Mophorlogical_Traits_Of_UC82B_Tomat o_Lycopersicon_Esculentum_Mill_Variety _in_Zaria_Nigeria.

Irwan, A. W., \& Wicaksono, F. Y. (2017). Perbandingan Pengukuran Luas Daun Kedelai dengan Metode Gravimetri, Regresi dan Scanner. Kultivasi, 16(3), 425429. https://doi.org/10.24198/kultivasi.v16i3.14 448. 
Istarofah \& Salamah, Z. (2017). Pertumbuhan Tanaman Sawi Hijau (Brassica juncea L.) dengan Pemberian Kompos Berbahan Dasar Daun Paitan (Thitonia diversifolia). Bio-site, 3(1), 39-46. https://onlinejournal.unja.ac.id/BST/article /view/3612/3130.

Khoir, M. S., Herlina, N., Koesriharti, \& Santoso, M. (2017). Pengaruh Pupuk NPK dan Kompos Kotoran Kelinci pada Pertumbuhan dan Hasil Tanaman Wortel (Daucus carota L.). Jurnal Produksi Tanaman, 5(6), 1029-1034. http://protan.studentjournal.ub.ac.id/index. $\mathrm{php} /$ protan/article/view/474/477.

Kholidin, M., Rauf, A., \& Barus, H. N. (2016). Respon Pertumbuhan dan Hasil Tanaman Sawi (Brassica juncea L.) terhadap Kombinasi Pupuk Organik, Anorganik dan Mulsa di Lembah Palu. J. Agrotekbis, 4(1), 1-7.

https://media.neliti.com/media/publications 1243063-none-83c5c2c3.pdf.

Kristanto, D., \& Aziz, S. A. (2019). Aplikasi Pupuk Organik Cair Urin Kelinci Meningkatan Pertumbuhan dan Produksi Caisim (Brassica juncea L.) Organik di Yayasan Bina Sarana Bakti, Cisarua, Bogor, Jawa Barat. Buletin Agrohorti, 7(3), 263-268.

https://doi.org/10.29244/agrob.v7i3.30192.

Kriswantoro, H., Safriyani, E., \& Bahri, S. (2016). Pemberian Pupuk Organik dan Pupuk NPK pada Tanaman Jagung Manis (Zea mays saccharata Sturt). Klorofil, 11(1), 1-6. https://doi.org/10.32502/jk.v11i1.209.

Kurniawati, H. Y., Karyanto, A., \& Rugayah. (2015). Pengaruh Pemberian Pupuk Organik Cair dan Dosis Pupuk Npk (15:15:15) Terhadap Pertumbuhan dan Produksi Tanaman Mentimun (Cucumis sativus L.). Jurnal Agrotek Tropika, 3(1), 30-35.

http://dx.doi.org/10.23960/jat.v3i1.1894.
Mulyani, H. (2014). Buku Ajar Kajian Teori dan Aplikasi Optimalisasi Perancangan Model Pengomposan. Jakarta: CV. Trans Info Media.

Mutryarny, E., Endriani, E., \& Lestari, S. U. (2014). Pemanfaatan Urine Kelinci untuk Meningkatkan Pertumbuhan dan Produksi Tanaman Sawi (Brassica juncea L.) Varietas Tosakan. Jurnal ilmiah Pertanian, 11(2), 23-34. https://doi.org/10.31849/jip.v11i2.1246.

Myers, C. (1998). Specialty and Minor Crops Handbook (Vol. 3346). California: UCANR Publications.

Nuryani, E., Haryano, G., \& Historiawati. (2019). Pengaruh Dosis dan saat Pemberian Pupuk $\mathrm{P}$ terhadap Hasil Tanaman Buncis (Phaseolus vulgaris L.) Tipe Tegak. Jurnal Ilmu Pertanian Tropika dan Subtropika, 4(1), 14-17. http://dx.doi.org/10.31002/vigor.v4i1.1307 . $\mathrm{g} 840$.

Peraturan Menteri Pertanian Nomor 70 tahun 2011 Tentang Pupuk Organik, Pupuk Hayati, dan Pembenah Tanah.

Pramitasari, H. E., Wardiyati, T., \& Nawawi, M. (2016). Pengaruh Dosis Pupuk Nitrogen dan Tingkat Kepadatan Tanaman Terhadap Pertumbuhan dan Hasil Tanaman Kailan (Brassica Oleraceae L.). Jurnal Produksi Tanaman, 4(1), 49-56. https://media.neliti.com/media/publications /131008-ID-none.pdf.

Rahmanda, A., Azizah, Z., \& Santoso, M. (2018). Pengaruh Aplikasi Kombinasi Biourin Sapi dengan EM4, Kotoran Sapi dan Pupuk Anorganik pada Pertumbuhan dan Hasil Tanaman Kacang Merahh (Phaseolus vulgaris L.). Jurnal Produksi Tanaman, 6(6),

$1118-1125$. http://protan.studentjournal.ub.ac.id/index. $\mathrm{php} / \mathrm{pr}$ otan/article/view/755/778.

Raksun, A., Japa, L., \& Mertha, I. G. (2019). Aplikasi Pupuk Organik dan NPK untuk 
Meningkatkan Pertumbuhan Vegetatif dan Produksi Buah Terong Hijau. Jurnal Penelitian Pendidikan IPA, 5(2), 159-164. https://doi.org/10.29303/jppipa.v5i2.188.

Ratag, S. P., Pangemanan, E. F., \& Tasirin, J. S. (2017). Kandungan Klorofil Dalugha (Crytosperma merkusii (Hassk.) Scott) pada Hutan Rawa Pasang Surut di Desa Laine, Pulau Sangihe. Eugenia, 23(1), 9-15. https://doi.org/10.35791/eug.23.1.2017.154 $\underline{10 .}$

Rinsema, W. J. (1983). Pupuk dan Cara Pemupukan. Jakarta: PT Bhratara Karya Aksara.

Rosdiana. (2015). Pertumbuhan Tanaman Pakcoy Setelah Pemberian Pupuk Urin Kelinci. Jurnal Matematika, Saint dan Teknologi, 16(1), 1-9. https://doi.org/10.33830/jmst.v16i1.218.20 $\underline{15}$.

Rusmawarni, Djufri, \& Supriatno. (2016). Pengaruh berbagai Konsentrasi Pupuk Organik Cair Urin Sapi dan Pupuk Hayati Bioboost terhadap Pertumbuhan Tanaman Stroberi (Fragaria virginiana). Jurnal Edu Bio Tropika, 4(2), 16-19. http://www.jurnal.unsyiah.ac.id/JET/articl elview/7129/5840.

Sarif, P., Hadid, A., dan Wahyudi, I. (2015). Pertumbuhan dan Hasil Tanaman Sawi (Brassica juncea L.) akibat Pemberian Berbagai Dosis Pupuk Urea. Agrotekbis, 3(5), 585-591. ISSN: 2338-3011. https://media.neliti.com/media/publication s/249324-pertumbuhan-dan-hasiltanaman-sawi-brass-5e12b59f.pdf.

Simanullang, A. Y., Kartini, N. L., \& Kesumadewi, A. A. I. (2019). Pengaruh Pupuk Organik dan Anorganik terhadap Pertumbuhan dan Hasil Tanaman Sawi Hijau (Brassica rapa L.). Agrotrop, 9(2), 166-177. https://doi.org/10.24843/AJoAS.2019.v09.i $\underline{02 . p 08}$

Sirot, T. A., Sudiarso, \& Santoso, M. (2017).
Pengaruh Biourin Kelinci dan Pupuk NPK pada Pertumbuhan dan Hasil Tanaman Jagung Manis (Zea mays saccharata Sturt.). Jurnal Produksi Tanaman, 5(12). 1942-1951. ISSN: 2527-8452. http://protan.studentjournal.ub.ac.id/index. php/protan/article/view/591/594.

Sukasana, I. W., Karnata, I. N., \& Irawan, B. (2019). Meningkatkan Pertumbuhan dan Hasil Pakcoy (Brassica rapa L.) dengan Mengatur Dosis Nutrisi AB Mix Agrifarm dan Umur Bibit secara Hidroponik. Ganec Swara, 13(2), 212-220. https://doi.org/10.35327/gara.v13i2.84.

Susantidiana \& Aguzaen, H. (2015). Pemberian Pupuk Organik Cair untuk Mengurangi Pemakaian Pupuk Anorganik pada Tanaman Kacang Tanah (Arachis hypogeae L.). Klorofil, 10(1), 19-27. https://doi.org/10.32502/jk.v10i1.192.

Tuquero, J., Chargualaf, R. G., \& Marutani, M. (2018). Growing Bok Choy (Brassica rapa Chinensis Group) Varieties for Guam. Food Plant Production. https://www.uog.edu/_resources/files/wptr c/BokChoy.pdf (Accessed on March 17, 2020).

Wahid, N. A., Laude, S., \& Bahrudin. (2015). Pengaruh Pemberian Kombinasi Pupuk Organik dan Anorganik terhadap Pertumbuhan dan Hasil Tanaman Sawi (Brassica juncea L.). J. Agrotekbis, 3(5), 571-578.

https://media.neliti.com/media/publications 1247164-none-a8a23e9a.pdf.

Wenno, S. J., \& Sinay, H. (2019). Kadar Klorofil Daun Pakcoy (Brassica chinensis L.) Setelah Perlakuan Pupuk Kandang dan Ampas Tahu sebagai Bahan Ajar Mata Kuliah Fisiologi Tumbuhan. Biopendix, $5(2)$, 130-139. https://doi.org/10.30598/biopendixvol5issu e2page130-139.

Wijayanti, P., Hastuti, E. D., \& Haryanti, S. (2019). Pengaruh Masa Inkubasi Pupuk dari 
Kurnianta, LD. et al. (2021). Jurnal BiologiTropis, 21 (1): 157 - 170

DOI: http://dx.doi.org/10.29303/jbt.v21i1.2426

Air Cucian Beras Terhadap Pertumbuhan Tanaman Sawi Hijau (Brassica juncea L.). Buletin Anatomi dan Fisiologi (Bulletin of
Anatomy and Physiology), 4(1), 2128.https://doi.org/10.14710/baf.4.1.2019.2 $1-28$. 